\title{
Molecular modeling of platinum (IV) complex as new drugs for anticancer chemotherapy
}

\author{
Abbas A-Ali Drea \\ Department of Chemistry-College of Science \\ University of Babylon, Hilla, Babylon, Iraq \\ Lekaa Hussain Khdaim \\ Department of Chemistry-College of Science \\ University of Babylon, Hilla, Babylon, Iraq
}

\begin{abstract}
Molecular modeling through theoretical calculation have been done to synthesis a new drugs for anticancer chemotherapy. Complex of (bis((4- methoxy -4- oxobutanoyl) oxy) bis methoxy amine )platinum (IV) chloride have been modeled synthesis as Prodrug molecule theoretically using density functional theory, DFT, B3LYP/LanL2DZ at level of theory. Geometry optimization have been calculated for all chemical species that's participate in the modulation. Energetic properties and all other characteristics properties have been calculated to estimate the general features of complex reactivity and stability toward the biochemical reactions.

They found that total energy value of geometry optimized structure equal to $\mathbf{- 1 4 8 2 . 3 9 8}$ a.u. The reactivity measurement by energy gap value $0.01141 \mathrm{kCal} \mathrm{mol}^{-1}$. Prodrug molecule have positive value of imaginary frequency, evidence for their stable complex is achieved through calculus of vibrational transition spectrum. Electronic transition calculation gave a clear view about the nature of chemical bonding and back donation of ligands.
\end{abstract}

Keywords - Molecular modeling, platinum (IV) complex, anticancer chemotherapy DFT, Theoretical calculation, Geometry optimization, Surface potential energy, and transition state.

\section{INTRODUCTION}

A lot of chemical compounds have been fabricated for medical uses, epically for Cancer diseases treatments. One of the famous chemical compounds as anticancer chemotherapy are Cis-platinum complexes and its derivatives of carboplatin [1,2] .Also oxaliplatin [3], nedaplatin[4] have been used widely in anticancer chemotherapy [5-6]. Square planer platinum(II)complex are acting as prodrugs containing two carrier ligands and two leaving groups, the two leaving group are exchanged in the cell platinum complex(IV) are possess ant malignant properties and can act as prodrugs. Novel platinum complex is large group in both Cis and Trans form with different donor ligand [7].Cisplatin is treatment small cell lung, ovarian, testicular, head, and neck tumors [8].The primary target of cisplatin is genomic DNA, specifically the N7 position of guanine bases [9]. Higher level of theory basis set into DFT calculation, that's implemented in package programs like Hyperchem program and Gaussian program been used to achieve a new model of drags or to proposed mechanism respect complex acting as prodrug for anticancer chemotherapy [10-14].

In the present work, modulation anew prodrug anticancer of platinum complex (IV) based on theoretical calculation that's will be done depending on DFT calculations. Geometry optimization process are proceed to get on physiochemical properties such as Mullikan charge ,EHOMO,ELUMO, energy gap $\Delta \mathrm{E}$, dipole moment $(\mu)$,total density, electrostatic potential ,Absolut electronegativity (X) ionization potential(I) chemical hardness ( $\eta$ ), chemical softness(S) and electron affinity(A) [15-17].

\section{COMPUTATIONAL DTAIL}

Different theoretical MO method have been used, that's implemented onto G09W [18] running on windows XP work station with core i7 . The geometry optimization of platinum complexes at DFT /B3Lyp [Becke's three parameter exchange functional along with the Lee-Yang-Parr nonlocal correlation functional [19-20]. Frequencies of vibration and electronic transitions have been calculated for platinum (IV) complexes using B3Lyp /LanL2DZ method. Calculus are done using restricted and unrestricted Hartree Fock respectively [21]. All characteristic properties of complexes, like ionization potential, Electron affinity, and others labeling phenomena have been calculated using Koopmans's theorem [22, 23]. 


\section{EXPERIMENT AND RESULT}

Geometry optimized structure of complexes have been calculated using DFT based on B3Lyp /LanL2DZ at level of theory in vacuumed. Figure 1. Represent the geometry optimized structure of complex A. Table 1. Represent the theoretical parameters of optimize geometry as bond length and bond angle of $\mathrm{Pt}(\mathrm{IV})$ complex.

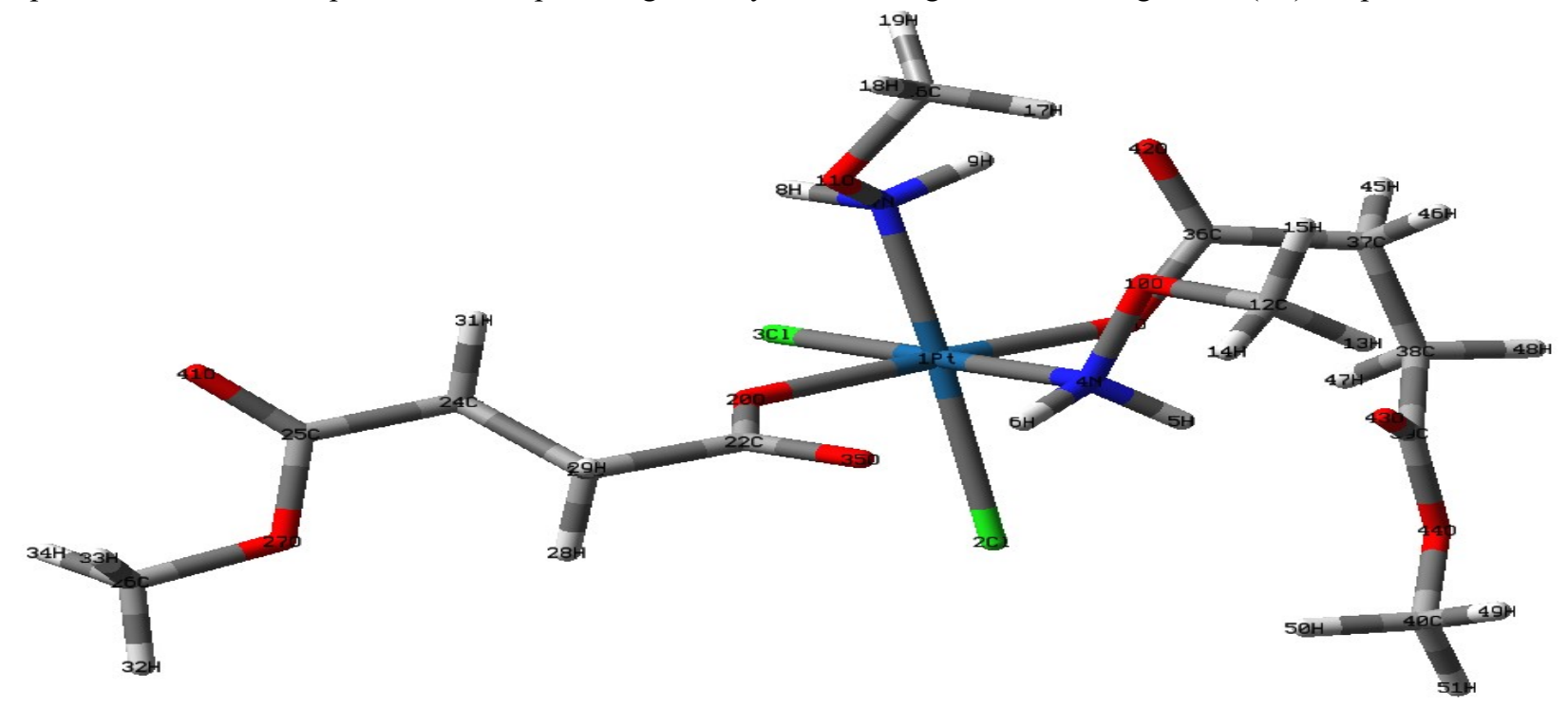

Figure 1. Geometry optimized for Pt (IV) complex by DFT/ B3Lyp/LanL2DZ (5d, 7f) at Level of theory.

Table 1. Theoretical parameter of bond length and bond angle Pt (IV) complex by using DFT/B3Lyp/LanL2DZ at level of theory.

\begin{tabular}{|c|c|c|c|c|c|}
\hline Bond type & $\begin{array}{c}\text { Length bond } \\
\mathrm{nm}\end{array}$ & Angle type & Bond angle $\AA$ & Dihedral Type & Dihedral \\
\hline $\mathrm{Pt}_{1}-\mathrm{N}_{21}$ & 1.97 & $\mathrm{Pt}_{1}-\mathrm{N}_{21}-\mathrm{O}_{22}$ & 120 & $\mathrm{Pt}_{1}-\mathrm{N}_{21}-\mathrm{O}_{22}-\mathrm{C}_{23}$ & -180 \\
\hline $\mathrm{Pt}_{1}-\mathrm{Cl}_{17}$ & 2.29 & $\mathrm{Pt}_{1}-\mathrm{N}_{18}-\mathrm{O}_{19}$ & 120 & $\mathrm{Pt}_{1}-\mathrm{N}_{18}-\mathrm{O}_{19}-\mathrm{C}_{20}$ & -180 \\
\hline $\mathrm{Pt}_{1}-\mathrm{O}_{3}$ & 1.94 & $\mathrm{~N}_{21}-\mathrm{Pt}_{1}-\mathrm{N}_{18}$ & 90 & $\mathrm{Pt}_{1}-\mathrm{O}_{3}-\mathrm{C}_{5}-\mathrm{C}_{7}$ & 90 \\
\hline & & $\mathrm{N}_{21}-\mathrm{Pt}_{1}-\mathrm{O}_{3}$ & 90 & $\mathrm{Pt}_{1}-\mathrm{O}_{2}-\mathrm{C}_{11}-\mathrm{O}_{12}$ & -90 \\
\hline & & $\mathrm{Cl}_{4}-\mathrm{Pt}_{1}-\mathrm{N}_{18}$ & 180 & $\mathrm{Pt}_{1}-\mathrm{O}_{2}-\mathrm{C}_{11}-\mathrm{C}_{13}$ & 90 \\
\hline & & $\mathrm{Cl}_{4}-\mathrm{Pt}_{1}-\mathrm{O}_{3}$ & 90 & $\mathrm{Pt}_{1}-\mathrm{O}_{3}-\mathrm{C}_{5}-\mathrm{O}_{6}$ & -90 \\
\hline
\end{tabular}

The symmetry of complex A form is $\mathrm{C} 1$ refer to asymmetrical distribution in the $\mathrm{Pt}(\mathrm{IV})$ complex .The output of this complex A gave $\mathrm{C} 1$ symmetry which is wrong symmetry [24].The dipole moment $(\mu)$ vary from 3 to 15 due to complex A is quite polar complex [5],the dipole moment values of complex for I.R and UV-Vis spectra is different $8.0922,6.2402$ respectively. The imaginary frequencies is positive and the energy values is negative ,therefore stable complex A .The physical an thermodynamic properties of complex A were calculated such as energy $\left(\mathrm{kCal} \mathrm{mol}^{-1}\right)$, heat of formation $\Delta \mathrm{H}$, Gibbs free energy $\Delta \mathrm{G}$, entropy $\Delta \mathrm{S}$, thermal energy .

Table 2. Thermodynamic calculation of Pt(IV)complex by using DFT/B3Lyp/Lan2DZ at 298.150K at levels of theory

\begin{tabular}{|l|l|}
\hline Total energy & $-1482.398 \mathrm{a} . \mathrm{u}$ \\
\hline Enthalpy $\Delta \mathrm{H}$ & $268.8867 \mathrm{Kcal} / \mathrm{Mol}$ \\
\hline Gibbs free energy & $202.4278 \mathrm{Kcal} / \mathrm{Mol}$ \\
\hline Entropy & $222.9042 \mathrm{Kcal} / \mathrm{Mol}$ \\
\hline Zaro point energy & $237.0818 \mathrm{Kcal} / \mathrm{Mol}$ \\
\hline Imaginary frequencies & + \\
\hline Time of calculation & $\mathrm{IR}=1 \mathrm{~h}: 17 \mathrm{~m}: 27 \mathrm{~s}$ and UV=8h:46m:8s \\
\hline Degree of freedom & 147 \\
\hline Kinetic energy & $1.375159960421 \mathrm{D}+03$ \\
\hline E-N energy & $-9.549360577589 \mathrm{D}+03$ \\
\hline
\end{tabular}




\begin{tabular}{|l|l|}
\hline N-N energy & $3.059532181679 \mathrm{D}+03$ \\
\hline
\end{tabular}

High electron density distribution on oxygen in carbonyl groups and nitrogen in amine group because the high value of electronegativity [25].The electrostatic potential in Figure 2,3, the negative charge are remarked by red color are distribution on the oxygen atoms in carbonyl groups and the nitrogen in amine group due to high value of electronegativity. The positive charge are remarked by green color are distribution on Carbone atoms[26].The Mullikan atomic charges give a positive value for $\mathrm{C}$ and $\mathrm{H}$ and negative values for $\mathrm{O}, \mathrm{N}, \mathrm{S}, \mathrm{Cl}$ atoms .Figure 4 .

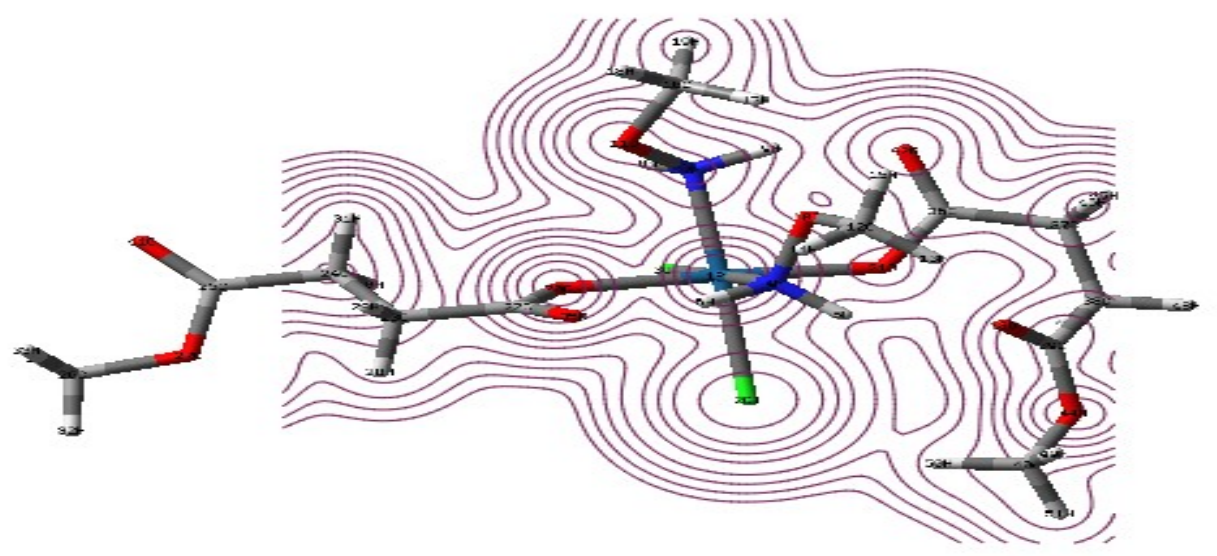

Figure 2. Total charge density for Pt(IV)complex by using DFT/B3Lyp/Lan2DZ at levels of theory.

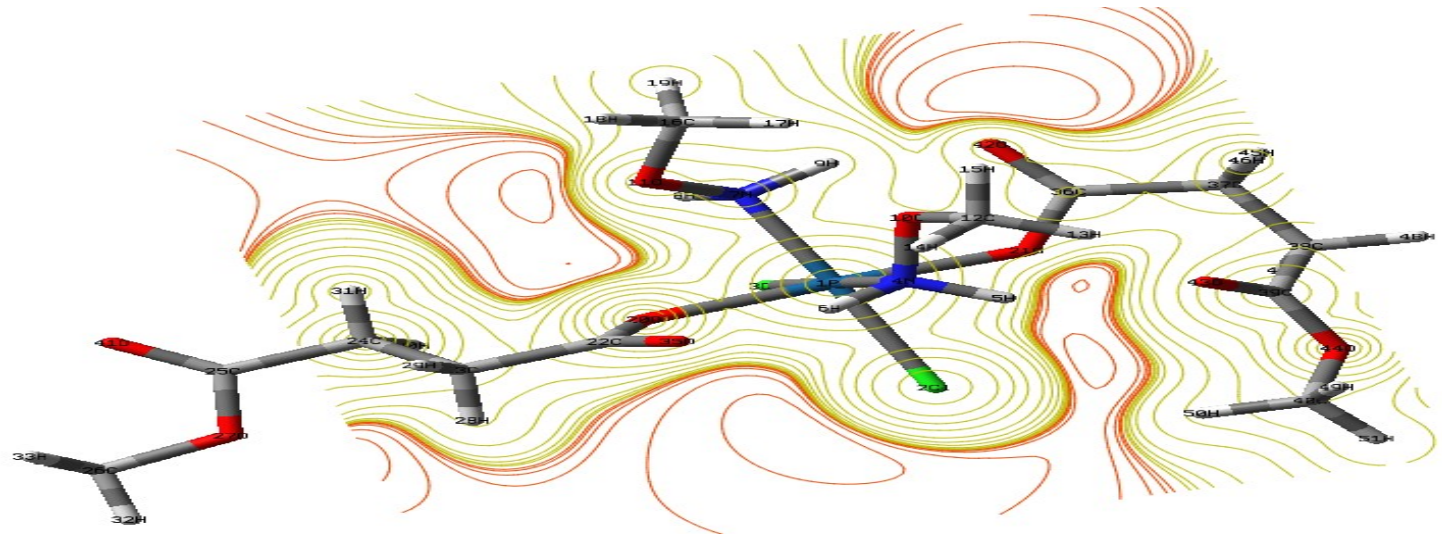

Figure 3. Electrostatic potential (ESP) for Pt (IV) complex by using DFT/B3Lyp/LanL2DZ at levels of theory. 


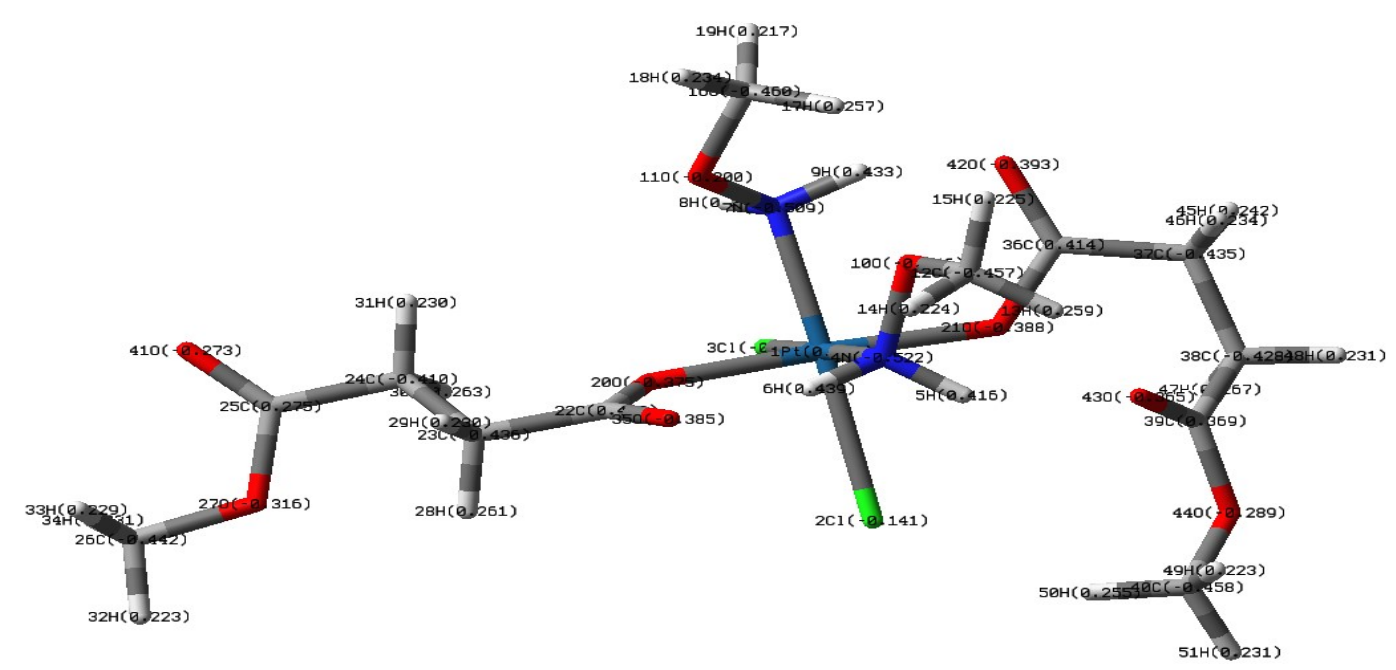

Figure 4. Mullikan atomic charge for Pt(IV)complex by using DFT/B3Lyp/LanL2DZ at levels of theory

\section{C-HOMO-LUMO Calculation}

Geometry optimization form for platinum (IV) complex described the frontal orbital's is useful to explore the interaction of surface metal's atoms and adsorption centers of the inhibitor molecule [27]. The value of HOMO energy is often associated with electron donating ability of complex ,but the energy of LUMO is ability to acceptor electron [28].The energy of HOMO $=-0.00239$, while the of LUMO $=0.00902$, low energy gap candidates this complex to be a good semiconductor and solar material. The reason behind this small gap is the extended of the metallic element platinum due to their availability in the HOMO energy level[29], table 2 .Figure5 .

Table 2. Physical properties for Pt (IV) complex at DFT/B3LYP/LanL2DZ (5D, 7F) at levels of theory.

\begin{tabular}{|l|l|}
\hline Type of calculation & Value of properties calculation \\
\hline HOMO energy & $-0.00239 \mathrm{Kcal} / \mathrm{Mol}$ \\
\hline LUMO energy & $0.00902 \mathrm{Kcal} / \mathrm{Mol}$ \\
\hline Energy gap & $0.01141 \mathrm{Kcal} / \mathrm{Mol}$ \\
\hline ionization potential & 0.26692 \\
\hline Electron affinity & 0.12087 \\
\hline electronegativity & 0.193895 \\
\hline chemical hardness & 0.073025 \\
\hline chemical softness & 13.69394 \\
\hline
\end{tabular}




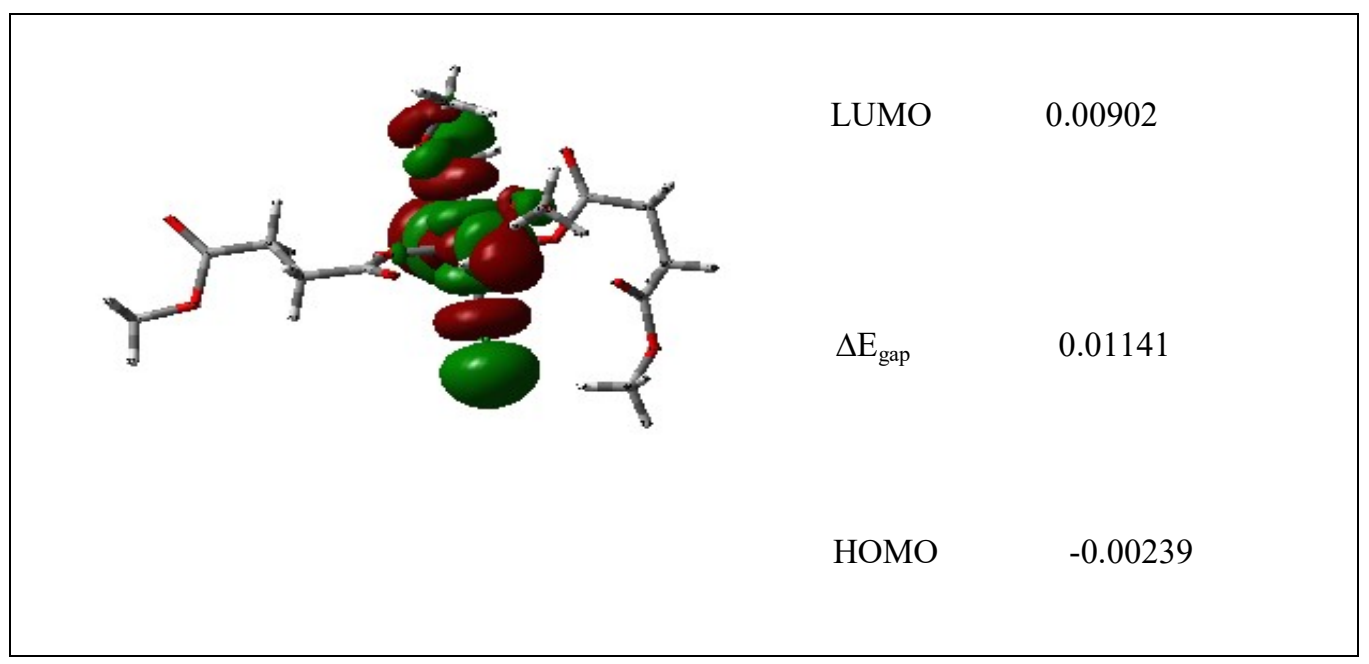

Figure 5. HOMO-LUMO of the geometry optimized Pt(IV)complex by DFT/B3LYP/LanL2DZ at levels of theory.

\section{D-Infrared spectroscopy study}

The theoretical I.R data for platinum (IV) complex was calculation by using DFT/B3LYP/LanL2DZ, table 3 show vibrational frequencies for complex A the limited refer to high intensity in IR spectra also description of type frequencies in complex A. The spectrum of complex shows band $2850-3000 \mathrm{~cm}^{-1}$ which due to $(\mathrm{C}-\mathrm{H})$ aliphatic ,the spectrum of complex show band $3300-3500 \mathrm{~cm}^{-1}$ which due to (N-H)stretching, the band in IR of complex at 1705$1725 \mathrm{~cm}^{-1}$ which due to $(\mathrm{C}=\mathrm{O})$, the band at $1000-1300 \mathrm{~cm}-1$ which due to $(\mathrm{C}-\mathrm{O})$ stretching, the two band $1515-1560$ \& 1345-1385 which due to (N-O)stretching . New bands have been occurred around (Pt-O), (Pt-Cl) (Pt-N)at $710 \mathrm{~cm}^{-1}$, $320 \mathrm{~cm}^{-1}, 568 \mathrm{~cm}^{-1}$ respectively as shown at Figure 6.

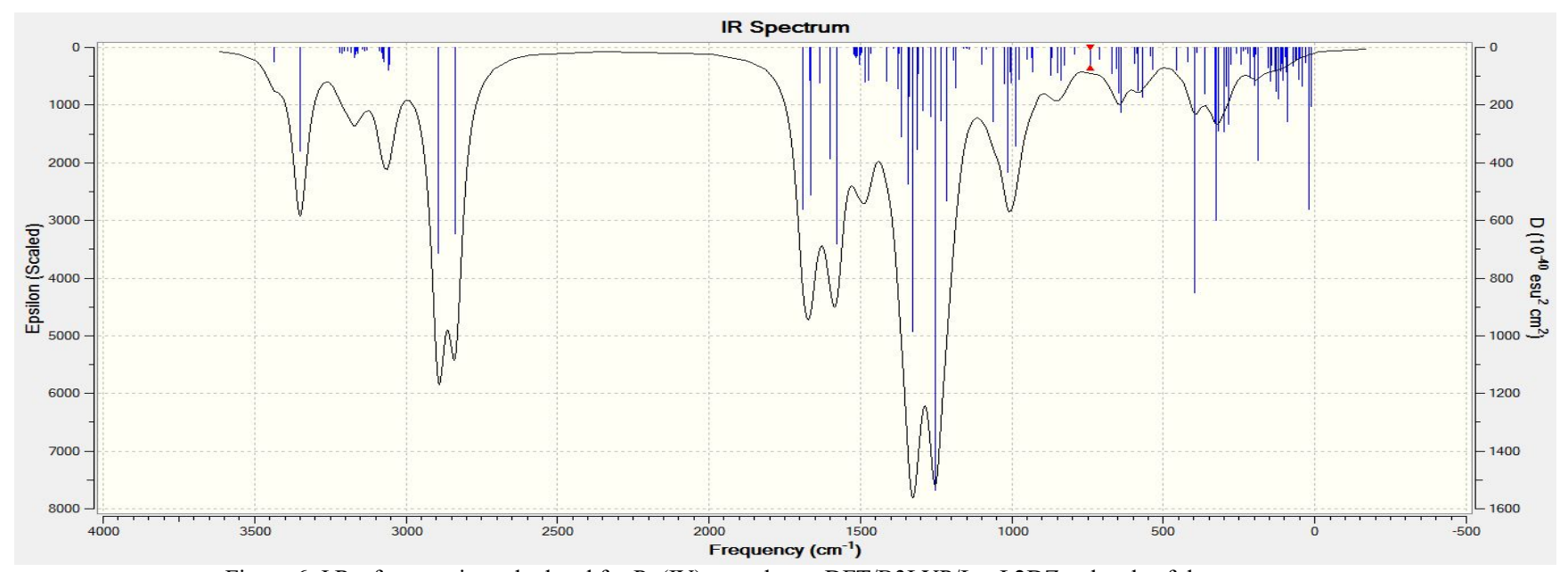

Figure 6. I.R.- frequencies calculated for Pt (IV) complex at DFT/B3LYP/LanL2DZ at levels of theory.

\section{E-Ultra-violet spectra}

The UV-Vis spectra of the complex A showed abroad band in visible region at $10000 \mathrm{~cm}^{-1}$ table 1 show transition state for complex A was characterized by different beak at high oscillator strength in select cell at (293 and 306) nm refer to $\left(\mathrm{n}-\delta^{*}\right)$ from $\mathrm{O} 4 \mathrm{Px}, \mathrm{y}, \mathrm{z}$ to $1 \mathrm{Pt}_{7 \mathrm{~d}}, 1 \mathrm{Pt}_{7 \mathrm{~d}+2}$, transition state other from $\mathrm{Cl}_{4 \mathrm{p} \mathrm{xy,z}}$ to $1 \mathrm{Pt}_{7 \mathrm{~d}}, 1 \mathrm{Pt}_{7 \mathrm{~d}+2}$, Figure 7 , and can be assignable to [30]. 


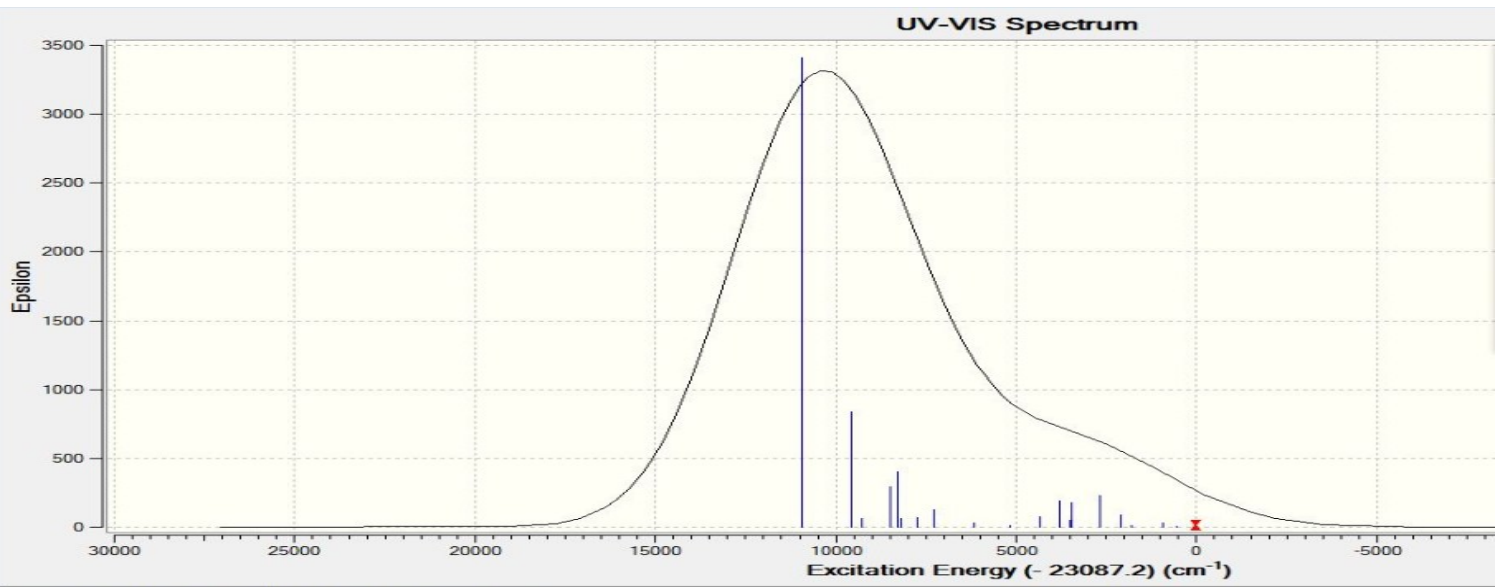

Figure 7. U.V-Vis spectra calculated for Pt(IV) complex at DFT/B3LYP/LanL2DZ at levels of theory

Table 1. Theoretical calculation for UV-Visible transition state for Pt(IV) complex at levels of theory

\begin{tabular}{|c|c|c|c|c|c|c|}
\hline \multicolumn{7}{|c|}{ Theoretical calculation } \\
\hline $\begin{array}{l}\text { Excitation } \\
\text { energy (ev) }\end{array}$ & $\begin{array}{l}\text { Wavelength } \\
(\mathrm{nm})\end{array}$ & $\begin{array}{l}\text { Oscillator } \\
\text { strength }\end{array}$ & Occ MO & $\begin{array}{l}\text { Unocc } \\
\text { MO }\end{array}$ & Coefficient & Explanation \\
\hline 3.1939 & 388.19 & 0.0039 & $\begin{array}{l}108 \\
110 \\
111 \\
\end{array}$ & $\begin{array}{l}113 \\
112 \\
113 \\
\end{array}$ & $\begin{array}{l}0.57435 \\
0.11820 \\
0.10744 \\
\end{array}$ & $\begin{array}{l}\mathrm{n}-\sigma^{*} \\
2 \mathrm{Cl}_{4 \mathrm{px}} \longrightarrow 1 \mathrm{pt}_{\mathrm{dd}+2} \\
3 \mathrm{Cl}_{4 \mathrm{px}} \longrightarrow \mathrm{pt}_{\mathrm{dd} 0} \\
35 \mathrm{O}_{4 \mathrm{px}} \longrightarrow \mathrm{pt}_{\mathrm{7d}+2}\end{array}$ \\
\hline 3.2895 & 376.91 & 0.0031 & $\begin{array}{l}106 \\
107 \\
109 \\
109 \\
110 \\
111\end{array}$ & $\begin{array}{l}112 \\
113 \\
112 \\
113 \\
112 \\
112 \\
\end{array}$ & $\begin{array}{l}0.25360 \\
0.27824 \\
0.10880 \\
0.22106 \\
0.29981 \\
0.36509 \\
\end{array}$ & 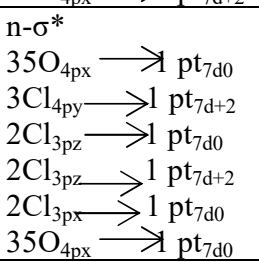 \\
\hline 3.3308 & 372 & 0.0033 & $\begin{array}{l}107 \\
107 \\
110 \\
111 \\
\end{array}$ & $\begin{array}{l}112 \\
113 \\
113 \\
113 \\
\end{array}$ & $\begin{array}{l}0.12380 \\
0.55124 \\
0.16756 \\
0.16750 \\
\end{array}$ & 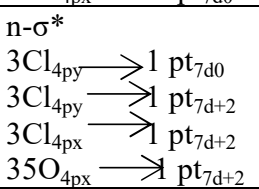 \\
\hline 3.8906 & 318.67 & 0.0069 & $\begin{array}{l}100 \\
102 \\
103 \\
106 \\
\end{array}$ & $\begin{array}{l}113 \\
112 \\
113 \\
112 \\
\end{array}$ & $\begin{array}{l}0.10286 \\
0.11850 \\
0.27107 \\
0.38060 \\
\end{array}$ & $\begin{array}{l}\mathrm{n}-\sigma^{*} \\
43 \mathrm{O}_{4 \mathrm{p} y} \rightarrow 1 \mathrm{pt}_{7 \mathrm{~d}+2} \\
20 \mathrm{O}_{4 \mathrm{py}} \rightarrow 1 \mathrm{pt}_{\mathrm{d} 0} \\
21 \mathrm{O}_{4 \mathrm{pz}} \longrightarrow 1 \mathrm{pt}_{\mathrm{dd}+2} \\
35 \mathrm{O}_{4 \mathrm{px}} \longrightarrow 1 \mathrm{pt}_{7 \mathrm{~d} 0}\end{array}$ \\
\hline 3.9171 & $316.52 \mathrm{~nm}$ & 0.0051 & $\begin{array}{l}100 \\
102 \\
102 \\
103 \\
105\end{array}$ & $\begin{array}{l}112 \\
112 \\
113 \\
112 \\
112\end{array}$ & $\begin{array}{l}0.11546 \\
0.45846 \\
0.15296 \\
0.19809 \\
0.20967\end{array}$ & $\begin{array}{l}\mathrm{n}-\sigma^{*} \\
43 \mathrm{O}_{4 \mathrm{py}} \longrightarrow \mathrm{pt}_{7 \mathrm{~d} 0} \\
20 \mathrm{O}_{4 \mathrm{py}} \rightarrow 1 \mathrm{pt}_{\mathrm{d} 0} \\
20 \mathrm{O}_{4 \mathrm{py}} \longrightarrow \mathrm{pt}_{\mathrm{dd}+2} \\
21 \mathrm{O}_{4 \mathrm{pz}} \longrightarrow \mathrm{pt}_{7 \mathrm{~d} 0} \\
42 \mathrm{O}_{4 \mathrm{px}} \longrightarrow 1 \mathrm{pt} 7 \mathrm{p} 0\end{array}$ \\
\hline 4.0511 & 306.05 & 0.0144 & $\begin{array}{l}102 \\
105\end{array}$ & $\begin{array}{l}113 \\
113\end{array}$ & $\begin{array}{l}0.49511 \\
0.17929\end{array}$ & $\begin{array}{l}\mathrm{n}-\sigma^{*} \\
20 \mathrm{O}_{4 \mathrm{py}} \longrightarrow \mathrm{pt}_{\mathrm{td}+2} \\
42 \mathrm{O}_{4 \mathrm{px}} \longrightarrow \mathrm{pt}_{7 \mathrm{~d}+2}\end{array}$ \\
\hline 4.2190 & 293.87 & 0.0585 & $\begin{array}{l}99 \\
100 \\
103\end{array}$ & $\begin{array}{l}112 \\
112 \\
113\end{array}$ & $\begin{array}{l}0.33411 \\
0.13319 \\
0.11235\end{array}$ & $\begin{array}{l}\mathrm{n}-\sigma^{*} \\
10 \mathrm{O}_{4 \mathrm{p} x} \longrightarrow 1 \mathrm{pt}_{7 \mathrm{~d} 0} \\
43 \mathrm{O}_{4 \mathrm{py}} \longrightarrow \mathrm{pt}_{7_{\mathrm{d} 0}} \\
21 \mathrm{O}_{4 \mathrm{pz}} \longrightarrow \mathrm{pt}_{7 \mathrm{~d}+2}\end{array}$ \\
\hline
\end{tabular}

F-NMR spectra 
Chemical shifts of $13 \mathrm{C}$ and $1 \mathrm{H}$-NMR in complex A were investigated by DFT /B3LYP/LanL2DZ (5D,7F) using NMR with GIAO. Calculated chemical shifts of $13 \mathrm{C}$ and $1 \mathrm{H}-\mathrm{NMR}$ in complex A are shown in Figure $8(\mathrm{a}, \mathrm{b})$. The chemical shifts of $13 \mathrm{C}$ and $1 \mathrm{H}-\mathrm{NMR}$ in complex A as referred by TMS were separated around $28 \mathrm{ppm}-192 \mathrm{ppm}$, and $1.75 \mathrm{ppm}-12.5 \mathrm{ppm}$, respectively. This behavior was influenced by magnetic shielding effect on the Pt(IV) complex .The separated chemical shifts of 13C and 1H-NMR were caused by nuclear spin interaction in carbon, and proton atoms on $\mathrm{Pt}(\mathrm{IV})$ complex . The chemical shift was mainly caused by hybridization of $\mathrm{d}$ spin in metal. The chemical shifts of $13 \mathrm{C}$ and $1 \mathrm{H}$ NMR Pt (IV) complex depended on the electron density distribution with a slight deviation of charge density on Pt (IV) complex [31]
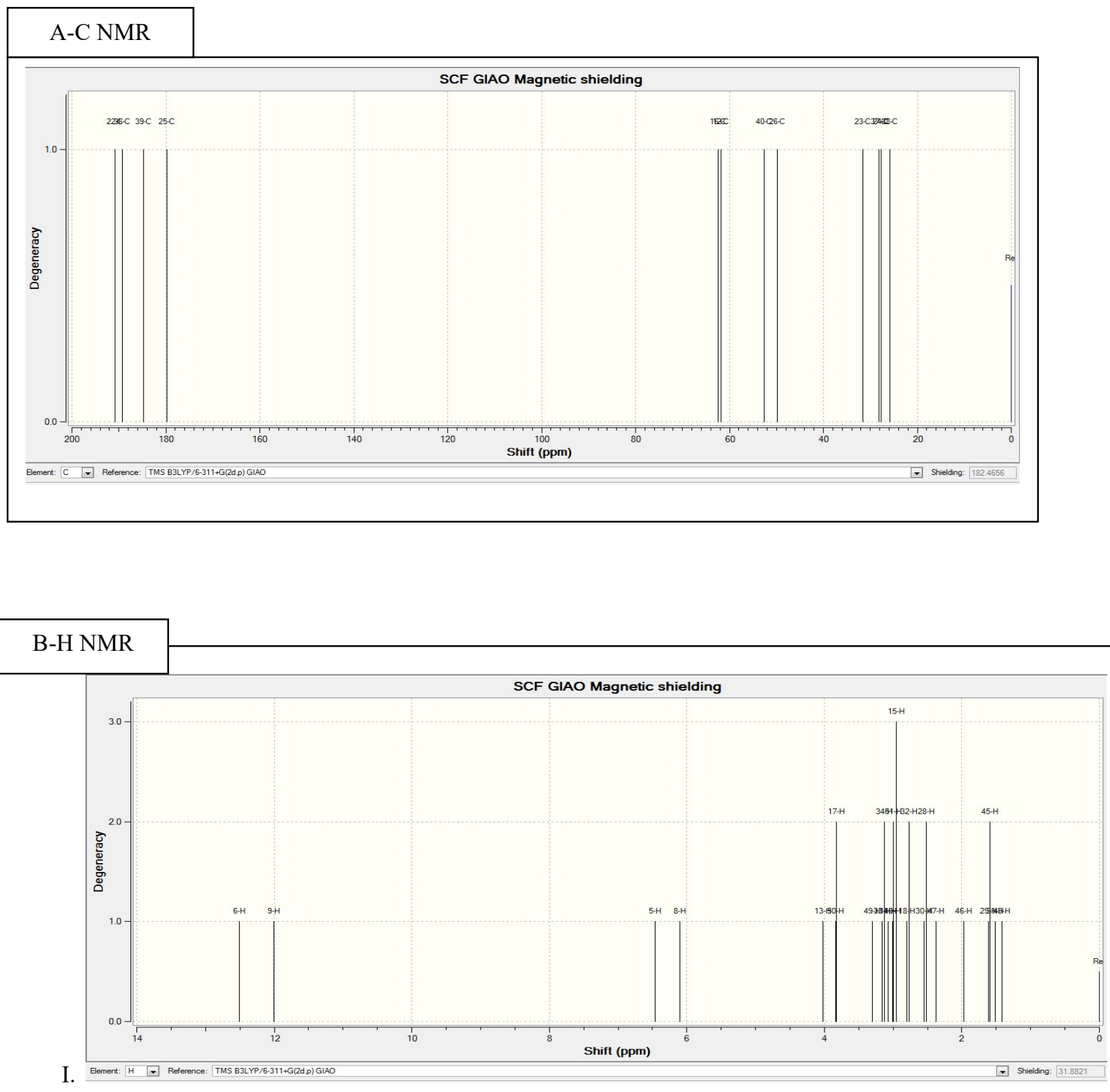

Figure 8. NMR spectra calculated for Pt(IV) complex at DFT/B3LYP/LanL2DZ at levels of theory.

\section{IV.CONCLUSION}

- The geometry optimized structure of Pt (IV) complex have been calculated using DFT based on B3Lyp /LanL2DZ at level of theory in vacuum. 
- The symmetry of complex A form is $\mathrm{C} 1$ refer to asymmetrical distribution in the complex $\mathrm{A}$. The output of this complex A gave $\mathrm{C} 1$ symmetry which is wrong symmetry

- Thermodynamic calculation of complex A by using DFT/B3Lyp/LanL2DZ which is endothermic and nonspontaneous $(268.8867,202.4278$ and energy gap is 0.01141 at $\mathrm{k} \mathrm{Cal} / \mathrm{mole}$ units.

- The stabilized structure of Pt(IV) complex comes out by total energy which equal to -1482.398 a.u units .

\section{REFERENCES}

[1] A. O. Dohn , K. B. Moller, S.P.A.Sawer, "optimizing the structure of tetracyano palatinate (II)": A comparison of relativistic density functional theory methods , current Inorganic chemistry, 3,pp.213-219,20113.

[2] J. M. Teuben, C.bauer, A.H wang, J.Biochemisty, 38, pp. 12305, 1999.

[3] B.Spingler, D.A.Whittington, S.J.lippard , inorg. Chem., 40, 5596, 2001

[4] M.J Picart, H.Lamb. J. B.Vermorken, Ann.Oncol, 12, pp.1195, 2001.

[5] H.P.Varbonov, M.A.Jakupec, A.Roller, F.Jensen .M.Galanski, B.K.Keppler, "theoretical Investigation and density functional theory basal quantitative structure - activity relationships model for noval cytotoxic platinum (IV) complex", J.meal . chem.293, 56, pp.330-344.

[6] H.S.Mohammed, I.S.Hamza, "DFT and MP2 study of Pd(II) and Ni(II), PhCN, DMSO and dithiooxamide complex" - part II : theortical . J. of Applicable chem., 2014,3(5), pp.2012-2122.

[7] B.R.J.Muhyedeen, A.A.Ali Drea, "synthesis and identification of Pd(II) and Ni(II) dithiooxamide complexes" - part I:Experimental .

[8] A.A.JAdjei, J.Clin, oncol, 1999, 17, pp.409-422.

[9] Arp,H, Baumgartner, J.Marschner C., Muller, T.,J.Am. chem., Soc. 2011, 133(15), pp.5632-5635.

[10] J.Ruzi, V.Rodrignez, C.D.Haro, A.Espinosa , J.PereZ,C.Janiak, "New 7-azaindole palladium and platinum complexes :crystal structure and theoretical calculation. In vitro and cancer activity of the platinum complexes ", Dalton trans., 2010, 39, pp.3290-3301.

[11] A.J.Abdul -Ghani, N.M.Abbas , "Bio inorganic chemistry and Application", 2011,Article ID 706262 ,pp.15.

[12] A.J.Abdul -Ghani, N.M.Abbas, "Bio inorganic chemistry and Application", 2009, articular ID 413175, pp.12.

[13] J.Kuwabara, T.Kanbara, J. of photopolymer science and tech. , 2008, 21(3), pp.349-353.

[14] G.L.Van de cappelle, M.A.Herman, Bulletin des Societes chimiques Belges, 1970,79,9-10,pp.585-592.

[15] H.Hofmans,H.O.Desseyn, A.T.H.Lenstra, Bull. Soc. Chem. Belg., 1985, pp.94, 705.

[16] F.Nastasi, F.Puntoriero, N.Palmer., S.Cavallaro, , S.Campagna,S.Lanza,chem,commun., 2007,pp.4740-4742.

[17] A.Giannetto, F.Puntorior, A.Barattucci, S.Lanza,S.Campanyna , Inorg. Chem., 2009, 48(21), pp.16397-10404.

[18] Gaussain09w, 2009, Revision A.I, Ver.7 Inc.340 Quinnipiac., Bldg.40, Wallingford CT 06492.

[19] AD Becke, J.Chem. Phys., 1993, 998.pp.1372-1377.

[20] C,Lee,W.Yang, R.G. parr, chem, phys. Lett 1992,pp.194,1.

[21] A.K.Rappe , C.J.Casewit , K.S.Colwell , W.A.Goddard III , W.M.Skiff, J.Am. chem, Soc, 1992,114, pp.10024,.

[22] L.Pauling, the nature of the chemical bond cornell univ., Ithaca, New york, 1960.

[23] R.G.Parr, R.A.Donnelly, M.Levy, W.Palke, J.chem .phys, 68, 1978, 3801.

[24] B.R.J.Muhyedeen, "'\qquantum and Molecular mechanics studies of free and complex conformation of 9-crown-3 and its azo and thio analogue", Iraqi J.chem . 2002, 28, 2.

[25] H.Th.Mohammod, "Simulation study of reaction mechanism for adrenaline and modulation analog moieties drugs ", thesis , M.sc., 2016.

[26] H.Adnan ,S.A.Aouwda and A.A.Drea , journal of applicable chemistry , 3(6), 2014, pp.2365-2371.

[27] A.A.Drea and N.Izet, journal of photocatalysis science, 2012, 3(2), pp.49-59.

[28] K.KF. "Corrosion control of copper in nitric acid solution using some amino acid -A combined experimental and theoretical study". Corros. Sci 2012, 52(10), pp.3225-3234.

[29] Y.Xie , Y.Liu, Z.Yang. "2-((5-mercopto-1, 3,4-thiodiazol-2-Ylimino)methyl-6-methoxy) Phenol sciff base as anew and effective corrosion inhibitor for mild steel in hydrochloric acid solution ". Int J.electochem , Sci, 2015 , 10 ,pp. 1292-1304.

[30] P.M.effendy . P.Claudio, H.W.Allan "The electronic spectra of the complex A was calculated by using the DFT/B3Lyp/Lan2DZ.", Inory, chem 42, 2003, pp.112-117.

[31] A. Suzuki and T.Oku," Theoretical Study of NMR, Infrared and Raman Spectra on Triple-Decker Phthalocyanines", The Irago Conference, 1709, 2015, pp.020013-1-020013-8. 